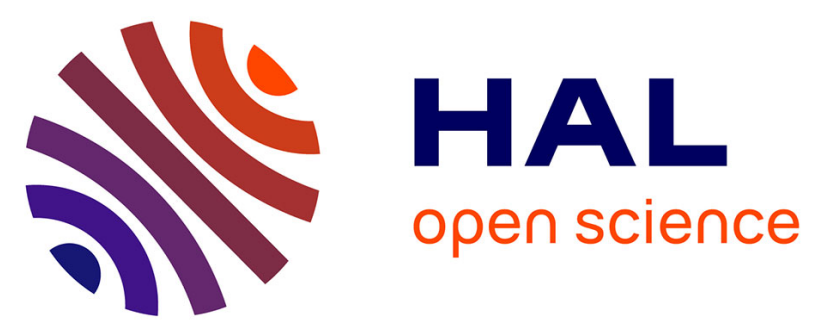

\title{
Acute Retinal Necrosis: Virological Features Using Quantitative Polymerase Chain Reaction, Therapeutic Management, and Clinical Outcomes
}

Meriem Hafidi, Hélène Janin-Manificat, Philippe Denis, Bruce Charleux, Muriel Rabilloud, Andre Boibieux, Carole Burillon, Laurent Kodjikian, Emilie Frobert

\section{To cite this version:}

Meriem Hafidi, Hélène Janin-Manificat, Philippe Denis, Bruce Charleux, Muriel Rabilloud, et al.. Acute Retinal Necrosis: Virological Features Using Quantitative Polymerase Chain Reaction, Therapeutic Management, and Clinical Outcomes. American Journal of Ophthalmology, 2019, 208, pp.376 - 386. 10.1016/j.ajo.2019.08.007 . hal-03488365

\section{HAL Id: hal-03488365 https://hal.science/hal-03488365}

Submitted on 21 Dec 2021

HAL is a multi-disciplinary open access archive for the deposit and dissemination of scientific research documents, whether they are published or not. The documents may come from teaching and research institutions in France or abroad, or from public or private research centers.
L'archive ouverte pluridisciplinaire HAL, est destinée au dépôt et à la diffusion de documents scientifiques de niveau recherche, publiés ou non, émanant des établissements d'enseignement et de recherche français ou étrangers, des laboratoires publics ou privés.

\section{(ㄷ)(1) $\$$}

Distributed under a Creative Commons Attribution - NonCommerciall 4.0 International 


\section{Acute retinal necrosis: virological features using quantitative PCR, therapeutic management, and clinical outcomes}

Meriem Hafidi, ${ }^{1}$ Hélène Janin-Manificat, ${ }^{1,2}$ Philippe Denis, ${ }^{3,4}$ Bruce Charleux, ${ }^{1}$ Muriel Rabilloud, ${ }^{3,5,6}$ Andre Boibieux, ${ }^{7}$ Carole Burillon, ${ }^{1,3}$ Laurent Kodjikian, ${ }^{3,4}$ Emilie Frobert, ${ }^{3,8,9}$

${ }^{1}$ Department of Ophthalmology, Edouard Herriot Hospital, Hospices Civils de Lyon, Lyon, France

${ }^{2}$ La Coline Ophthalmological Center, Clinique I'Infirmerie Protestante, Caluire et Cuire, France

${ }^{3}$ University of Lyon, Lyon, France

${ }^{4}$ Department of Ophthalmology, Croix Rousse Hospital, Hospices Civils de Lyon, Lyon, France

${ }^{5}$ Department of Biostatistics and Bioinformatics, Hospices Civils de Lyon, Lyon, France

${ }^{6}$ Laboratory of Biometry and Evolutive Biology, CNRS, UMR 5558, Equipe

Biostatistique-Santé, Villeurbanne, France

${ }^{7}$ Department of Infectious Diseases, Croix Rousse Hospital, Hospices Civils de Lyon, Lyon, France

${ }^{8}$ Laboratory of Virology, Institut des Agents Infectieux (IAI) de Lyon, Hospices Civils de Lyon, Lyon, France

${ }^{9}$ Centre International de Recherche en Infectiologie (CIRI), Inserm U1111, Centre National de la Recherche Scientifique (CNRS) UMR5308, Ecole Nationale Supérieure de Lyon (ENS), Equipe Virpath, Lyon, France

\section{Corresponding author:}

Dr. Meriem Hafidi

Department of Ophthalmology, Pavillon C

Edouard Herriot Hospital

5, Place d'Arsonval

Lyon 69003, France

Tel: +33 (0)4 72116217

Fax: +33 (0)4 72116238

E-mail: meriem.hafidi1@gmail.com

Supplemental Material available at AJO.com.

Short title: Management and outcomes of acute retinal necrosis. 


\section{Introduction}

Acute retinal necrosis (ARN) syndrome is a rare viral retinitis caused by the varicella zoster virus (VZV), herpes simplex virus (HSV) type 1 or 2, and, more rarely, by cytomegalovirus (CMV). ${ }^{1}$ It was first described in 1971 by Urayama et al. as a unilateral panuveitis with retinal vasculitis and necrotizing retinitis, and occurring in both immunocompetent and immunocompromised hosts. ${ }^{2,3}$ The prognosis is often poor, with severe visual loss and retinal detachment, despite intensive antiviral therapy. ${ }^{4,5}$

Polymerase chain reaction (PCR) is a rapid and sensitive method for the detection of viral DNA that is useful for the diagnosis of ARN. ${ }^{6-9}$ With recent advances in molecular biology, real-time quantitative PCR (qPCR) enables quantitative measurements of the viral load. ${ }^{10}$ A correlation between the clinical course and viral load kinetics has been reported in other herpes virus-related infections such as encephalitis and chickenpox. ${ }^{11,12}$ In cases of ARN syndrome, qPCR revealed that a high VZV DNA copy number is associated with more extensive retinitis, worse visual acuity (VA), and the development of retinal detachment (RD). ${ }^{13,14}$ Furthermore, a few case series have described the kinetics of viral DNA during systemic treatment and suggested that qPCR may be a useful method to monitor viral activity and the patient's response to antiviral therapeutics. ${ }^{15-17}$

There are significant variations in treatment practices, especially concerning the use of intravitreal injections (IVTs). ${ }^{18}$ Many studies have reported the efficacy of IVTs of foscarnet or ganciclovir, ${ }^{19-22}$ but there are no guidelines for therapeutic indications, duration, or dose. The purpose of the present report was to assess the role of qPCR in the therapeutic management of ARN syndrome, and to evaluate the outcomes of patients treated with intensive intravitreal therapy.

\section{Methods}

This study was a retrospective observational case series of 24 patients with ARN in the Departments of Ophthalmology of the Croix-Rousse and Edouard Herriot Teaching Hospitals (Lyon, France) who were treated and followed-up between May 2010 and December 2016. Cases were identified from the virology department database that contained the qPCR results of herpes viruses from samples of the aqueous humor $(\mathrm{AH})$. All patients met the criteria for ARN defined by the American Uveitis Society. ${ }^{23}$ Written informed consent was obtained from all participants. The ethics committee of the Hospices Civils de Lyon (Lyon, France) approved this study, and the study was performed according to the tenets of the Declaration of Helsinki.

\section{Patients and clinical assessment}

Each patient's medical record was retrospectively reviewed to obtain the following demographic data: age at presentation, gender, laterality, history of a herpetic infection, duration of symptoms prior to presentation, previous medical history (specifically, the presence of a disease altering cellular or humoral immunity, or use of immunosuppressive therapy in order to assess the immune status of the patient). In addition, the causal virus and results of any antiviral resistance investigation were also collected.

The following ophthalmologic characteristics were collected: initial and final best corrected visual acuity (BCVA); initial number of retinal quadrants involved, defined after 
dilated funduscopic examination; and occurrence of complications. Visual acuity was assessed using Snellen charts and converted to the logarithm of the minimum angle of resolution (logMAR). For visual acuities $<20 / 400$, the following logMAR conversions were used: counting fingers $=1.6$, hand movement $=2$, light perception $=2.5 .^{21,24}$ Details of the systemic antiviral medication and intravitreal injections were collected.

\section{DNA viral load}

Viral DNA was extracted using an automatic nucleic acid platform (NucliSENS EasyMAG, BioMérieux, Lyon, France) from samples of the AH obtained after anterior chamber paracentesis (ACP; $200 \mu \mathrm{L}$ in $50 \mu \mathrm{L}$ of elution buffer), as recommended by the manufacturer. Real-time qPCR was performed using HSV1, HSV2, VZV, and CMV Rgene $^{\mathrm{TM}}$ Quantification kits (Argène, BioMérieux). Results were expressed as copies of DNA per $\mathrm{mL}$ of $\mathrm{AH}$ (the threshold of quantification was 500 copies per $\mathrm{mL}$ and that of detection was 100 copies per $\mathrm{mL}$ ).

\section{Antiviral resistance}

HSV UL23 and UL30 genes, which, respectively, encode thymidine kinase and DNA polymerase, were sequenced using Sanger technology as reported previously. ${ }^{25}$ Nucleotide sequences were compared with those of the sensitive reference strains KOS (HSV1) and HG52 (HSV2; GenBank accession numbers JQ673480 and Z86099, respectively) using Seqmanll software (DNAStar Inc, Wisconsin, USA).

VZV resistance was investigated by sequencing ORF28 and ORF36 that encodie DNA polymerase and thymidine kinase, respectively. Sequences were compared to the wild-type OKA strain (GenBank accession number AB097933). ${ }^{26}$

\section{Statistical analysis}

Quantitative characteristics were described using the median and range. Qualitative characteristics were described using the absolute and relative frequencies in each category.

The main outcome was the difference between the final and initial VA, expressed in logMAR. The comparison of the final and initial VA was performed using the Wilcoxon test, a non-parametric test for paired data.

A linear mixed model with a random intercept and a random slope was created to estimate the mean slope corresponding to the mean decrease in the logarithm (log) of the viral load per day, and the gaps of the individual slopes to the mean slope. The fixed regression coefficients of the linear mixed model were used to estimate the mean time to achieve a $50 \%$ reduction in viral load and to decrease to the detection threshold of the viral load (< 100 copies $/ \mathrm{mL}$ ).

The Kaplan-Meier method was used to estimate the probability of the occurrence of RD.

Statistical significance was defined as a two-tailed $P$ value of $<0.05$. The analyses were performed using IBM SPSS Statistics for Windows, Version 21.0 (IBM Corp., Armonk, NY, USA) and R version 3.2.5 (R Core Team 2017. R: A language and environment for statistical computing. R Foundation for Statistical Computing, Vienna, Austria). 


\section{Results}

The initial patient characteristics are reported in Table 1.

\section{Demographic data}

Samples from 25 eyes of 24 patients were collected (13 females, 11 males); the mean duration of follow-up was 17 months (range: 2-74 months). The infectious agent was VZV in 15 patients (62.5\%), HSV1 in 4 patients (16.7\%), HSV2 in 3 patients $(12.5 \%)$, and CMV in 2 patients (8.3\%). The median age at presentation was 58 years (range: 20-86 years). Patients with HSV2 were significantly younger (median age: 32 years; range: 20-34 years) than those with another virus (median age: 60 years; range: $40-86$ years; $P=0.001)$. Eight patients $(33.3 \%)$ were immunocompromised and 12 patients $(50.0 \%)$ had a history of previous herpes infection.

\section{Clinical features at presentation}

The median duration of symptoms (first clinical signs to initiation of treatment) was 7 days (range: 1-45 days). The median initial VA was 0.8 logMAR (Snellen equivalent, 20/125). Eleven eyes (44\%) had an initial VA $\leq 20 / 200 ; 11$ eyes (44\%) had an initial VA of 20/200-20/40; and 3 eyes (12\%) had an initial VA > 20/40. Retinitis occurred in one quadrant in 3 eyes (12\%), two quadrants in 6 eyes (24\%), three quadrants in 2 eyes (8\%), and four quadrants in 10 eyes (40\%). The fundus was inaccessible due to hyalitis in 4 eyes $(16 \%)$. One patient had initial bilateral involvement and RD in 1 eye. One patient had a central retinal artery occlusion (CRAO) at presentation.

\section{Visual acuity outcomes}

The VA was significantly improved $(P=0.04)$ (mean: -0.29 logMAR; median: -0.2 logMAR; range: -1.09 to -1 logMAR). The distributions of the initial and final VA of each patient are presented in Figure 1. The distributions of VAs according to the causative virus are presented in Supplemental Material 2 at AJO.com. Among patients with VZV, the median gain in VA was -0.2 logMAR (range: -1.9 to 0.6 logMAR). Patients with HSV1 ARN had a median gain of -0.2 logMAR (range: -1.2 to $1 \log M A R$ ). All patients with HSV2 showed improved VA, the median gain was -0.8 logMAR (range: -0.9 to -0.1 logMAR). One case of CMV ARN had a final VA of 20/20; the other had a final VA of 20/100 (mean gain, 0.05 logMAR). Overall, the final VA was $\leq 20 / 200$ for 5 eyes (20\%), 20/200-20/40 (inclusive) for 12 eyes (48\%), and > 20/40 for 8 eyes (32\%). Among the 16 patients who were followed for at least 1 year, the final VA was $\leq 20 / 200$ for 4 eyes (25\%), 20/200-20/40 (inclusive) for 8 eyes (50\%), and > 20/40 for 4 eyes $(25 \%$ ).

There was no significant difference in final VA between patients treated with corticosteroids (median VA $0.45 \mathrm{log})$ and the others $(0.5 \mathrm{log} ; P=0.59)$.

\section{Retinal detachment outcomes}

In total, 4 eyes (16\%) developed RD, which occurred between presentation and 5 months after the diagnosis of ARN. The probability of the occurrence of RD was estimated to be $18.5 \%$ at year $1(95 \% \mathrm{Cl}[1.8 \% ; 35.2 \%])$.

\section{Therapeutic management}

The details of the therapeutic management and clinical evolution of each patient are summarized in Table 2. 


\section{Initial antiviral treatment}

The initial antiviral treatment was administered intravenously to 23 patients and orally (valacyclovir, $1000 \mathrm{mg}, 3$ times daily) to 1 patient (\#1). To manage VZV and HSV $A R N$, intravenous acyclovir was used as first-line therapy for 17 patients $(77 \%)$, administered at a dose of $10 \mathrm{mg} / \mathrm{kg}$ every 8 hours; it was replaced by a combination of intravenous foscarnet and ganciclovir for 2 very severe cases (\#8, \#11) including the case of CRAO (\#8). Ganciclovir was used intravenously for one immunocompromised patient (\#4). Foscarnet was used intravenously for 3 patients (13.6\%; \#7, \#10, \#16) initially and was secondarily used with acyclovir in 1 patient. Patients with CMV ARN were treated with intravenous ganciclovir. Intravenous treatment was continued until complete resolution of retinitis; the median duration was 24 days (range: 15-48 days).

\section{Intravitreal treatment}

Twenty-two eyes (88\%) received at least one IVT of an antiviral agent (ganciclovir and/or foscarnet) in combination with systemic therapy. Seventeen patients received the same treatment regimen: initial intensive treatment with biweekly injections for the duration of intravenous treatment, followed by weekly injections according to the clinical course and change in viral load. The median number of IVTs was 9 (range: 0-28). Ganciclovir (2000 $\mathrm{\mu g} / 0.05 \mathrm{~mL}$ ) was administered to 14 eyes; foscarnet $(2.4 \mathrm{mg} / 0.1 \mathrm{~mL})$ was administered to all patients with CMV infection and to 4 patients with VZV infection (2 were immunocompromised). Two patients $(\# 8, \# 12)$ received a combination of foscarnet and ganciclovir. For one patient (\#17), the drug was switched, from ganciclovir to foscarnet, after 7 IVTs due to the slow clinical improvement and a delay in reduction of the viral load. Ten patients were treated with injections until the viral load was undetectable.

\section{Oral antiviral therapy}

All patients received oral antiviral therapy with valacyclovir (20 patients) or valganciclovir (4 patients) as a part of the intravenous therapy. This was continued for all patients until the most recent follow-up.

\section{Corticotherapy}

Corticosteroid therapy (1 mg/kg/day) was introduced to 10 patients (46\%); this started between 3 and 60 days after initiation of antiviral treatment (median: 16.5 days) and allowed clinical improvement for all patients. Four patients (\#4, \#5, \#14, \#15) were already receiving low-dose corticosteroids (less than $20 \mathrm{mg} /$ day) before the occurrence of ARN, and the dosage was not changed.

\section{Viral DNA}

Viral kinetics

A quantification of the viral load was obtained at least once for all patients, and a change over time was evaluated in the 19 patients who had $\geq 2$ samples. Details of observed and predicted reductions of viral load over time are reported in Figure 2. Patient 5 had bilateral involvement with RD; the viral load in the detached eye could not be quantified. The median number of the samples was 8 (range: 1-24 samples); the only complication related to ACP was the occurrence of an iatrogenic cataract. 
The initial mean viral load was 811591 copies $/ \mathrm{mL}$ (5.91 log) for VZV, 1794023 copies $/ \mathrm{mL}(6.25 \mathrm{log})$ for CMV, and $1794023 \mathrm{copies} / \mathrm{mL}(6.12 \mathrm{log})$ for HSV1. The initial viral load was lower in the HSV2 group (66240 copies/mL; $4.82 \mathrm{log}$ ) than in the VZV group $(P=0.09)$. Among the total population, the viral load at time 0 was estimated to be $5.87 \mathrm{log}$, which corresponds to a mean viral load at time 0 of $738268(95 \% \mathrm{Cl}[325696$; 1673463]). In order to obtain a homogeneous population for assessment of the initial evolution of viral load, we analyzed the viral loads of 17 patients who received the same combined systemic (intravenous acyclovir) and intravitreal treatment. We observed an initial plateau in 8 patients. A plateau was defined as a change in viral load of less than $10 \%$ in patients for whom we had a minimum of 2 samples during the first week. We could not judge the presence or absence of a plateau in the 5 patients who had had only one measurement in the first week. The median duration of the plateau in these patients was 15.5 days (range: 7-28 days). The remaining 4 patients experienced a reduction in the viral load on initiation of treatment.

The mean decrease in viral load was estimated to be -0.076 log per day $(95 \% \mathrm{Cl}$ [-0.93; -0.59]; $P<0.001$ ); the mean time required to achieve a $50 \%$ reduction in viral load was estimated to be 3.95 days for all viruses and 4.20 days for the VZV group. The mean decreases in viral loads according to the type of virus are presented in Supplemental Material 1 at AJO.com.

The mean time required for viral load to be below the detection threshold was estimated to be 50.9 days. In the 10 patients who had an undetectable final viral load, this was achieved after a mean 56.1 days (range: $27-119$ days).

Role of immune competence

Mean baseline viral load was 2401728 copies/mL (6.38 log; range, 14300013000000 copies $/ \mathrm{mL}$ ) in the immunocompromised group and 822144 copies $/ \mathrm{mL}$ (5.9 log; range, 2400-6100000 copies $/ \mathrm{mL}$ ) in the non-immunocompromised group. This difference was not statistically significant $(P=0.35)$.

There was no significant difference in the rate of decrease in viral load between immunocompromised patients (mean decrease in viral load: -0.067 log per day) and the others $(0.074 \log ; P=0.37)$.

Role of corticotherapy

No significant difference was observed in the decrease in viral load between patients treated with corticosteroids and those who were not (mean decrease in viral load: -0.071 log per day vs. -0.073 log per day; $P=0.89$ ).

\section{Resistance to antivirals}

Antiviral resistance was investigated in $3 \mathrm{HSV} 1$ patients (patients \#16, \#17, and \#19), and 3 VZV patients (patients \#13, \#14, and \#15). Among the HSV1 patients, patient \#17 tested positive for mutation of the thymidine kinase gene. In this patient, duration of the plateau phase was significantly longer (28 days) compared to other patients in the series, who also had a plateau (11.6 days; $P=0.04)$. The plateau phase corresponded to treatment with intravenous acyclovir and IVTs of ganciclovir; the decrease ensued after replacement of ganciclovir with foscarnet. 
With DNA polymerase sequencing, we did not find a resistance mutation in any of the 3 patients. In the VZV patients, the DNA sequences were unfortunately incomplete, and all regions could not be analyzed. No mutation related to resistance was found in the sequences tested.

\section{Discussion}

To the best of our knowledge, the present study is the largest series to describe the evolution of the viral load of ARN using qPCR during treatment. The antiviral treatment regimen used was largely homogeneous, and included initial intravenous therapy combined with bi-weekly IVTs, followed by oral therapy with weekly IVTs. This treatment protocol yielded good outcomes in terms of VA and the RD rate.

Half of the included patients had a history of herpes infection, making it an important and often reported diagnostic guidance element. ${ }^{27}$ It is assumed that ARN occurs when immune dysfunction allows the herpes virus to reactivate.$^{29} \mathrm{It}$ is of note that a third of patients included herein were immunosuppressed, which is higher than that reported in the literature. ${ }^{3}$ This is an important clinical consideration for the choice of antivirals since resistance to acyclovir is common in such patients. ${ }^{30}$

The retrospective nature and the variable duration of follow-up are the primary sources of bias of the present study. The limited follow-up period of some patients may have resulted in an underestimation of the rate of RD, however, it is reported that $96 \%$ of the cases of RD occur early, within 5 months of onset of the first symptoms. ${ }^{7}$

Furthermore, when tracking bias was taken into account by using Kaplan-Meier analysis, the probability of RD herein remained the lowest rate reported in the literature (Table 3).

In the present study, a clinically significant improvement in VA and only a fifth of patients had a final VA $\leq 20 / 200$, compared to $46 \%$ in the literature. ${ }^{44}$ The markedly better visual outcomes herein could be explained by the use of IVT, but also the intensive and extended antiviral treatment administered to each patient. For instance, it has been demonstrated that IVTs are beneficial for VA and decrease the risk of $R D .^{20,21,42}$ It can be assumed that in cases of occlusive vasculitis, retinal penetration of systemic antiviral treatment may be decreased, and IVTs may intensify the treatment by increasing the intraocular concentrations and accelerating healing. Furthermore, the median number of IVTs was high compared to other series, wherein only 1 to 7 injections were administered. ${ }^{21,22,36,51,52}$ As for the duration of use, it is interesting to note that on the study reported by Meghpara et al., IVTs were used for a mean duration of 59 days and good outcomes were found. ${ }^{20}$

We observed a change in the viral load in 3 phases: a first plateau period that was not always present, a logarithmic decrease phase, and a negativation phase. The first study that described this profile of viral load during treatment of VZV ARN was performed by Bernheim et al. ${ }^{15}$ In their study, the initial plateau and the delay of the time to negativity were longer, probably related to the differences in treatment used.

Additional studies are needed to support the role of IVT in the decrease of the viral load. We continued ACP and IVTs until negativation of the viral load in 10 cases. As ACP is a minimally invasive procedure with infrequent side effects, ${ }^{53}$ the repetition of this technique to achieve negativity seems acceptable to ensure healing. Some authors recommend performing a puncture when injecting $0.1 \mathrm{~mL}$ of a substance to avoid a short-term increase in intraocular pressure. Thus, the frequency of the punctures could be adapted to that of the IVT. Since a significant complication occurred herein, it seems 
reasonable to reduce the number of punctures to improve safety. ${ }^{37}$ It is, however, not possible to establish a direct relationship between the viral load and the clinical course since other factors, such as immune status or corticosteroid therapy, come into consideration. However, it is logical to presume that the final VA is improved in cases of rapid healing and when the viral load decreases rapidly.

Acyclovir is the first-line treatment for HSV and VZV ARN, due to its efficacy and good tolerability, ${ }^{38}$ and herein it was used as such in most cases. The median duration of intravenous therapy was much longer than the duration more commonly used in clinical practice (7 to 10 days). The duration of intravenous treatment was decided by the treating ophthalmologists, based on their preferences with respect to the resolution of retinitis.

No study has previously described the change in viral load in the context of resistance to acyclovir; a prolonged plateau, as observed in the present study, could be a reason to change the treatment and test for resistance. Resistance to acyclovir is more common in immunosuppressed patients, ${ }^{39}$ which may favor the administration of foscarnet as a first-line therapy. In addition, synergy is observed between foscarnet and ganciclovir in vitro, which may justify their use as dual therapy in severe cases. We used a combination of ganciclovir and foscarnet (intravitreal or intravenous) for a highly immunocompromised patient, and for extremely severe ARN. In the case with CRAO, intraretinal penetration of intravenous antivirals was probably minimal, IVTs of ganciclovir and foscarnet were also used to achieve the highest intraocular concentration.

Oral treatment was traditionally initiated as an adjunct to intravenous treatment to reduce the risk of bilateralization. ${ }^{40}$ In the present study, it was continued for all patients until the most recent follow-up visit. Recent studies have also demonstrated its effectiveness when administered from the initial phase of management, ${ }^{41,42}$ as we observed in one patient herein. Intravenous antiviral therapy was the reference at the time of patient management; however, it could be replaced by oral treatment, as both strategies are associated with similar outcomes. ${ }^{24}$ There is no recommendation for the duration of preventive treatment, but it seems justified to continue long-term treatment due to the risk of recurrence and bilateralization, which may occur years after the first episode. ${ }^{43}$ Systemic corticosteroids are often co-administered with antiviral therapy to reduce local inflammation. ${ }^{44}$ They very likely play an important role in the decrease of the viral load but this has was not demonstrated herein, probably due to heterogeneous introduction date and duration of use. The time of introduction is often discussed in the litterature because of the risk of aggravation if the infection is insufficiently controlled by the antiviral treatment, but no study has formally investigated this aspect.

In conclusion, numerous and prolonged IVTs, used as ajdunctive therapy, could improve the prognosis of treated patients by decreasing the risk of retinal detachment and improving visual acuity. Real-time qPCR enables monitoring of the response to treatment and can provided evidence for resistance to antiviral treatment by enabling the detection of cases with a prolonged initial plateau of viral load. 
Acknowledgments/Disclosure: The authors would like to thank Philip Robinson (DRCl, Hospices Civils de Lyon, Lyon, France) for help in manuscript preparation.
a. Funding/Support: None.
b. Financial Disclosures: No financial disclosures.
c. Other Acknowledgments: None. 


\section{References}

1. Ganatra JB, Chandler D, Santos C, Kuppermann B, Margolis TP. Viral causes of the acute retinal necrosis syndrome. Am J Ophthalmol 2000;129(2):166-172.

2. Urayama A, Yamada N, Sasaki T. Unilateral acute uveitis with retinal periarteritis and detachment. Rinsho Ganka 1971;25:607-619.

3. Rochat C, Herbort CP. [Acute retinal necrosis syndrome. Lausanne cases, review of the literature and new physiopathogenetic hypothesis]. Klin Monbl Augenheilkd 1994;204(5):440-449.

4. Roy R, Pal BP, Mathur G, Rao C, Das D, Biswas J. Acute retinal necrosis: clinical features, management and outcomes - a 10 year consecutive case series. Ocul Immunol Inflamm 2014;22(3):170-174.

5. $\quad$ Sims JL, Yeoh J, Stawell RJ. Acute retinal necrosis: a case series with clinical features and treatment outcomes. Clin Exp Ophthalmol 2009;37(5):473-477.

6. Knox CM, Chandler D, Short GA, Margolis TP. Polymerase chain reaction-based assays of vitreous samples for the diagnosis of viral retinitis. Use in diagnostic dilemmas. Ophthalmology 1998;105(1):37-44;discussion 44-45.

7. Lau CH, Missotten T, Salzmann J, Lightman SL. Acute retinal necrosis: features, management, and outcomes. Ophthalmology 2007;114(4):756-762.e1.

8. Sugita S, Shimizu N, Watanabe K, et al. Use of multiplex PCR and real-time PCR to detect human herpes virus genome in ocular fluids of patients with uveitis. $\mathrm{Br} \mathrm{J}$ Ophthalmol 2008;92(7):928-932.

9. Gargiulo F, De Francesco MA, Nascimbeni G, et al. Polymerase chain reaction as a rapid diagnostic tool for therapy of acute retinal necrosis syndrome. $J$ Medical Virol 2003;69(3):397-400.

10. Dworkin LL, Gibler TM, Van Gelder RN. Real-time quantitative polymerase chain reaction diagnosis of infectious posterior uveitis. Arch Ophthalmol 2002;120(11):15341539.

11. Kimura H, Kido S, Ozaki T, et al. Comparison of quantitations of viral load in varicella and zoster. J Clin Microbiol 2000;38(6):2447-2449.

12. Ando Y, Kimura H, Miwata H, Kudo T, Shibata M, Morishima T. Quantitative analysis of herpes simplex virus DNA in cerebrospinal fluid of children with herpes simplex encephalitis. J Med Virol 1993;41(2):170-173.

13. Abe T, Sato M, Tamai M. Correlation of varicella-zoster virus copies and final visual acuities of acute retinal necrosis syndrome. Graefes Arch Clin Exp Ophthalmol 1998;236(10):747-752.

14. Calvo CM, Khan MA, Mehta S, Garg SJ, Dunn JP. Correlation of clinical outcomes with quantitative polymerase chain reaction DNA copy number in patients with acute retinal necrosis. Ocul Immunol Inflamm 2017;25(2):246-252.

15. Bernheim D, Germi R, Labetoulle M, Romanet JP, Morand P, Chiquet C. Time profile of viral DNA in aqueous humor samples of patients treated for varicella-zoster virus acute retinal necrosis by use of quantitative real-time PCR. J Clin Microbiol 2013;51(7):2160-2166.

16. Asano $\mathrm{S}$, Yoshikawa $\mathrm{T}$, Kimura $\mathrm{H}$, et al. Monitoring herpesvirus DNA in three cases of acute retinal necrosis by real-time PCR. J Clin Virol 2004;29(3):206-209.

17. Cottet L, Kaiser L, Hirsch HH, Baglivo E. HSV2 acute retinal necrosis: diagnosis and monitoring with quantitative polymerase chain reaction. Int Ophthalmol 2009;29(3):199-201. 
18. Winterhalter S, Stuebiger N, Maier A-K, et al. Acute retinal necrosis: diagnostic and treatment strategies in Germany. Ocul Immunol Inflamm 2016;24(5):537-543.

19. Luu KK, Scott IU, Chaudhry NA, Verm A, Davis JL. Intravitreal antiviral injections as adjunctive therapy in the management of immunocompetent patients with necrotizing herpetic retinopathy. Am J Ophthalmol 2000;129(6):811-813.

20. Meghpara B, Sulkowski G, Kesen MR, Tessler HH, Goldstein DA. Long-term follow-up of acute retinal necrosis. Retina 2010;30(5):795-800.

21. Yeh S, Suhler EB, Smith JR, et al. Combination systemic and intravitreal antiviral therapy in the management of acute retinal necrosis syndrome. Ophthalmic Surg Lasers Imaging Retina 2014;45(5):399-407.

22. Wong R, Pavesio CE, Laidlaw DAH, Williamson TH, Graham EM, Stanford MR. Acute retinal necrosis: the effects of intravitreal foscarnet and virus type on outcome. Ophthalmology 2010;117(3):556-560.

23. Holland GN. Standard diagnostic criteria for the acute retinal necrosis syndrome. Executive Committee of the American Uveitis Society. Am J Ophthalmol 1994;117(5):663-667.

24. Tibbetts MD, Shah CP, Young LH, Duker JS, Maguire JI, Morley MG. Treatment of acute retinal necrosis. Ophthalmology 2010;117(4):818-824.

25. Frobert E, Cortay J-C, Ooka T, et al. Genotypic detection of acyclovir-resistant HSV-1: characterization of $67 \mathrm{ACV}$-sensitive and $14 \mathrm{ACV}$-resistant viruses. Antiviral Res 2008;79(1):28-36.

26. Andrei G, Topalis D, Fiten P, et al. In vitro-selected drug-resistant varicella-zoster virus mutants in the thymidine kinase and DNA polymerase genes yield novel phenotype-genotype associations and highlight differences between antiherpesvirus drugs. J Virol 2012;86(5):2641-2652.

27. Okafor K, Lu J, Thinda S, et al. Acute retinal necrosis presenting in developmentally-delayed patients with neonatal encephalitis: a case series and literature review. Ocul Immunol Inflamm 2017;25(4):563-568.

28. Tran THC, Stanescu D, Caspers-Velu L, et al. Clinical characteristics of acute HSV-2 retinal necrosis. Am J Ophthalmol 2004;137(5):872-879.

29. Rochat C, Polla BS, Herbort CP. Immunological profiles in patients with acute retinal necrosis. Graefes Arch Clin Exp Ophthalmol 1996;234(9):547-552.

30. Gilbert C, Bestman-Smith J, Boivin G. Resistance of herpesviruses to antiviral drugs: clinical impacts and molecular mechanisms. Drug Resist Updat 2002;5(2):88-114. 31. Fisher JP, Lewis ML, Blumenkranz M, et al. The acute retinal necrosis syndrome. Part 1: Clinical manifestations. Ophthalmology 1982;89(12):1309-1316.

32. Clarkson JG, Blumenkranz MS, Culbertson WW, Flynn Jr HW, Lewis ML. Retinal detachment following the acute retinal necrosis syndrome. Ophthalmology 1984;91(12):1665-1668.

33. Matsuo T, Morimoto K, Matsuo N. Factors associated with poor visual outcome in acute retinal necrosis. Br J Ophthalmol 1991;75(8):450-454.

34. Crapotta JA, Freeman WR, Feldman RM, et al. Visual outcome in acute retinal necrosis. Retina 1993;13(3):208-213.

35. Tran THC, Bodaghi B, Rozenberg F, Cassoux N, Fardeau C, LeHoang P. [Viral cause and management of necrotizing herpetic retinopathies]. J Fr Ophtalmol 2004;27(3):223-236.

36. Tran THC, Cassoux N, Bodaghi B, Lehoang P. Successful treatment with 
combination of systemic antiviral drugs and intravitreal ganciclovir injections in the management of severe necrotizing herpetic retinitis. Ocul Immunol Inflamm 2003;11(2):141-144.

37. Kotliar K, Maier M, Bauer S, Feucht N, Lohmann C, Lanzl I. Effect of intravitreal injections and volume changes on intraocular pressure: clinical results and biomechanical model. Acta Ophthalmologica Scandinavica. 2007;85(7):777-781.

38. Morel C, Metge F, Roman S, et al. [Acute retinal necrosis: clinical presentation, treatment, and prognosis in a series of 22 patients]. J Fr Ophtalmol 2004;27(1):7-13.

39. Frobert E, Burrel S, Ducastelle-Lepretre S, et al. Resistance of herpes simplex viruses to acyclovir: an update from a ten-year survey in France. Antiviral Res. 2014;111:36-41.

40. Aizman A, Johnson MW, Elner SG. Treatment of acute retinal necrosis syndrome with oral antiviral medications. Ophthalmology 2007;114(2):307-312.

41. Muthiah MN, Michaelides M, Child CS, Mitchell SM. Acute retinal necrosis: a national population-based study to assess the incidence, methods of diagnosis, treatment strategies and outcomes in the UK. Br J Ophthalmol 2007;91(11):1452-1455. 42. Ishida T, Sugamoto $Y$, Sugita S, Mochizuki M. Prophylactic vitrectomy for acute retinal necrosis. Jpn J Ophthalmol 2009;53(5):486-489.

43. Hillenkamp J, Nölle B, Bruns C, Rautenberg P, Fickenscher H, Roider J. Acute retinal necrosis: clinical features, early vitrectomy, and outcomes. Ophthalmology 2009;116(10):1971-1975.e2.

44. Wong R, Pavesio CE, Laidlaw DAH, Williamson TH, Graham EM, Stanford MR. Acute retinal necrosis: the effects of intravitreal foscarnet and virus type on outcome. Ophthalmology 2010;117(3):556-560.

45. Taylor SR, Hamilton R, Hooper CY, et al. Valacyclovir in the treatment of acute retinal necrosis. BMC Ophthalmology 2012;12(1):48.

46. Cochrane TF, Silvestri G, McDowell C, Foot B, McAvoy CE. Acute retinal necrosis in the United Kingdom: results of a prospective surveillance study. Eye 2012;26(3):370378.

47. Luo YH, Duan XC, Chen BH, Tang LS, Guo XJ. Efficacy and necessity of prophylactic vitrectomy for acute retinal necrosis syndrome. Int $\mathrm{J}$ Ophthalmol 2012;5(4):482-487.

48. Jeon S, Kakizaki H, Lee WK, Jee D. Effect of prolonged oral acyclovir treatment in acute retinal necrosis. Ocul Immunol Inflamm 2012;20(4):288-292.

49. Iwahashi-Shima C, Azumi A, Ohguro N, et al. Acute retinal necrosis: factors associated with anatomic and visual outcomes. Jpn J Ophthalmol 2013;57(1):98-103.

50. Flaxel CJ, Yeh S, Lauer AK. Combination systemic and intravitreal antiviral therapy in the management of acute retinal necrosis syndrome (an American Ophthalmological Society thesis). Trans Am Ophthalmol Soc 2013;111:133-144.

51. Huang JM, Callanan P, Callanan D, Wang RC. Rate of retinal detachment after early prophylactic vitrectomy for acute retinal necrosis. Ocul Immunol Inflamm 2016;26(2):204-207.

52. Butler NJ, Moradi A, Salek SS, et al. Acute retinal necrosis: presenting characteristics and clinical outcomes in a cohort of polymerase chain reaction-positive patients. Am J Ophthalmol 2017;179:179-189.

53. Kishore K, Jain S, Zarbin MA. Intravitreal ganciclovir and dexamethasone as adjunctive therapy in the management of acute retinal necrosis caused by varicella 
zoster virus. Ophthalmic Surg Lasers Imaging 2011;42 Online:e87-90.

54. Patel P, Ahmed E, Subramanian ML. Intravitreal foscarnet therapy for acyclovirresistant acute retinal necrosis after herpes simplex encephalitis. Ophthalmic Surg Lasers Imaging 2010;9:1-3.

55. Van der Lelij A, Rothova A. Diagnostic anterior chamber paracentesis in uveitis: a safe procedure? Br J Ophthalmol 1997;81(11):976-979.

56. Blumenkranz MS, Culbertson WW, Clarkson JG, Dix R. Treatment of the acute retinal necrosis syndrome with intravenous acyclovir. Ophthalmology 1986;93(3):296300.

57. Emerson GG, Smith JR, Wilson DJ, Rosenbaum JT, Flaxel CJ. Primary treatment of acute retinal necrosis with oral antiviral therapy. Ophthalmology 2006;113(12):22592261.

58. Aslanides IM, De Souza S, Wong DTW, et al. Oral valacyclovir in the treatment of acute retinal necrosis syndrome. Retina 2002;22(3):352-354.

59. La Cava M, Abbouda A, Restivo L, Zito R. Delayed onset of bilateral acute retinal necrosis syndrome: a 46-year interval. Semin Ophthalmol 2015;30(2):146-149.

60. Shantha JG, Weissman HM, Debiec MR, Albini TA, Yeh S. Advances in the management of acute retinal necrosis. Int Ophthalmol Clin 2015;55(3):1-13. 


\section{Captions}

FIGURE 1. Distributions of initial and final visual acuity. CMV, cytomegalovirus, HSV, herpes simplex virus, VZV, varicella zoster virus.

FIGURE 2. Observed and predicted reductions of viral load over time. 


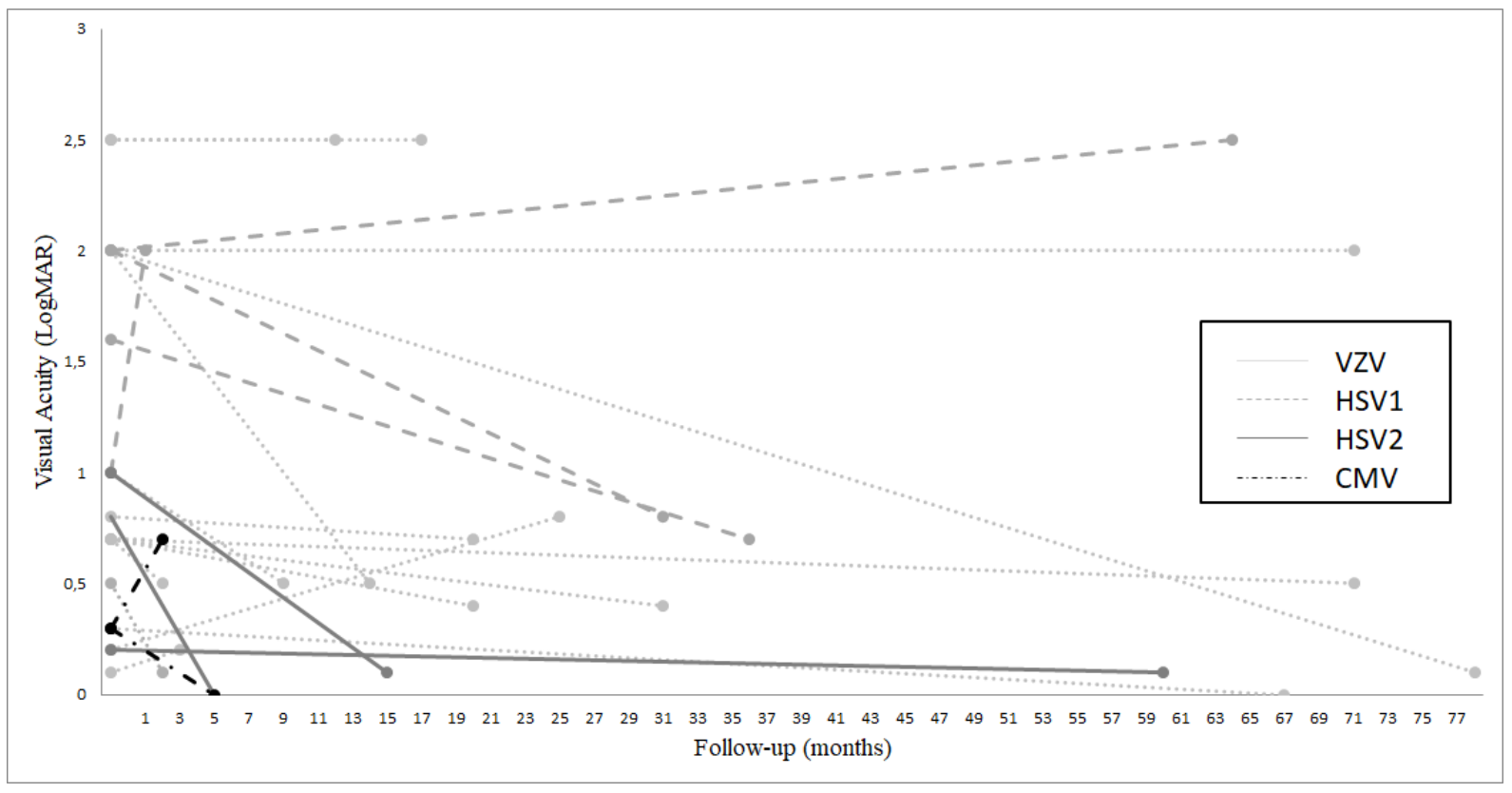




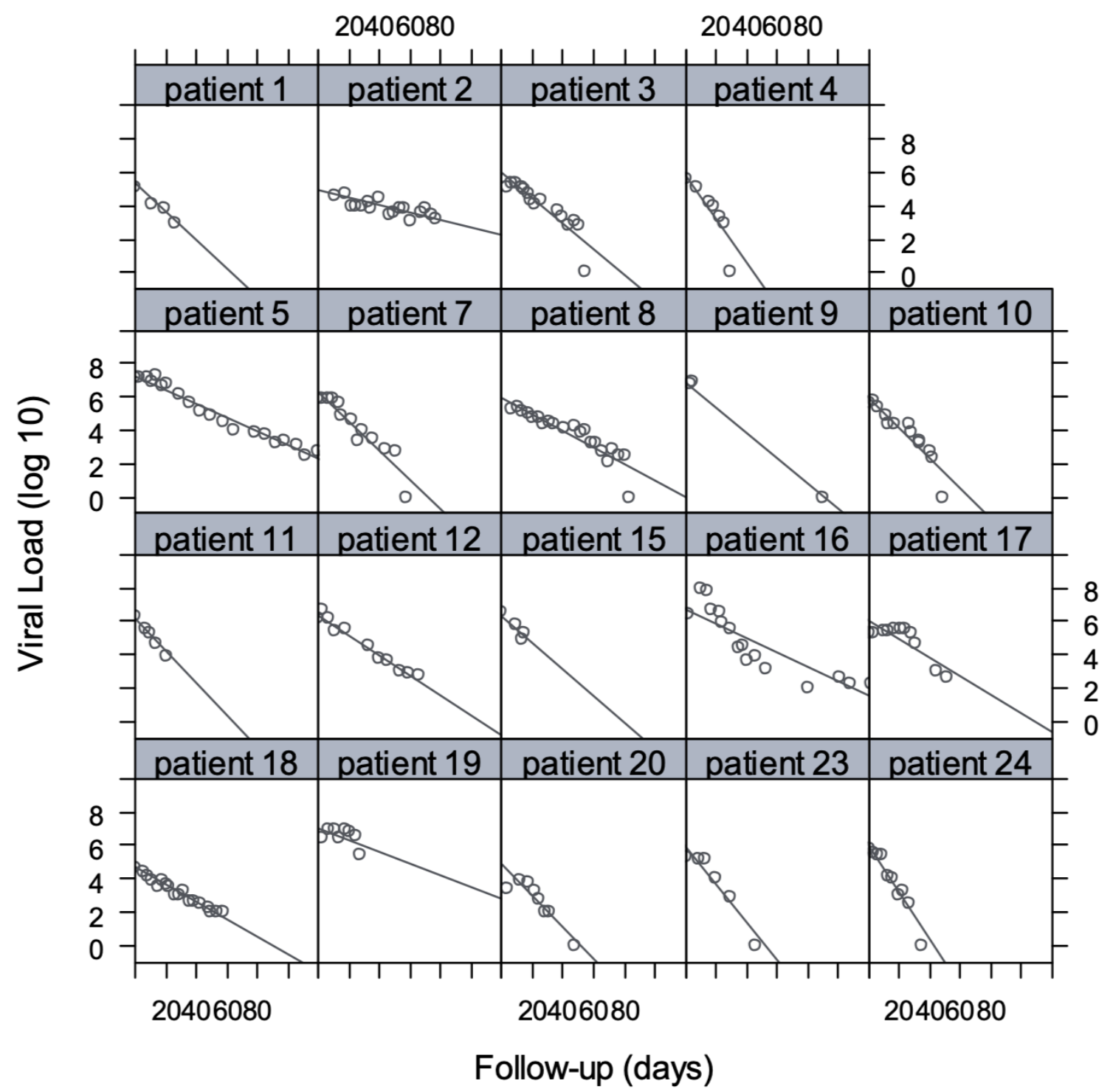




\begin{tabular}{|c|c|c|c|c|c|c|c|c|c|c|c|c|}
\hline Patient & Age & Gender & Virus & Prior herpetic infection & $\begin{array}{l}\text { Immune } \\
\text { dysfunction } \\
\text { (ID) }\end{array}$ & Type of immunosuppression & Laterality & $\begin{array}{l}\text { Symptom } \\
\text { duration } \\
\text { (days) }\end{array}$ & $\begin{array}{l}\text { Presenting } \\
\text { VA }\end{array}$ & $\begin{array}{l}\text { Quadrants } \\
\text { of retinitis }\end{array}$ & $\begin{array}{l}\text { Duration of } \\
\text { follow-up } \\
\text { (months) }\end{array}$ & $\begin{array}{l}\text { Other } \\
\text { clinical } \\
\text { findings } \\
\text { at } \\
\text { diagnosis }\end{array}$ \\
\hline 1 & 65 & $\mathrm{~F}$ & VZV & No & YES & Lung cancer, chemotherapy & OD & 15 & $20 / 200$ & 2 & 10 & \multirow{24}{*}{$\begin{array}{l}\text { Initial RD } \\
\\
\text { Initial } \\
\text { CRAO }\end{array}$} \\
\hline 2 & 80 & $\mathrm{M}$ & VZV & No & NO & & OS & 10 & $20 / 100$ & 2 & 21 & \\
\hline 3 & 42 & $\mathrm{~F}$ & VZV & No & NO & & OD & 3 & $20 / 32$ & 1 & 26 & \\
\hline 4 & 60 & M & VZV & Thorax shingles ( 2 month prior) & YES & $\begin{array}{l}\text { IgA nephropathy, } \\
\text { corticosteroids }\end{array}$ & OS & 7 & $20 / 40$ & 2 & 68 & \\
\hline $\begin{array}{l}5(\mathrm{OD}) \\
5(\mathrm{OS})\end{array}$ & 76 & M & VZV & -9 & YES & $\begin{array}{l}\text { Rheumatoid arthritis, } \\
\text { corticosteroids }\end{array}$ & $\mathrm{OU}$ & 7 & $\begin{array}{l}20 / 100 \\
\mathrm{HM}\end{array}$ & $\begin{array}{l}1 \\
4\end{array}$ & 74 & \\
\hline 6 & 48 & M & VZV & $\begin{array}{l}\text { Zoster ophthalmicus ( } 9 \text { days } \\
\text { prior) }\end{array}$ & NO & & OS & 1 & $20 / 100$ & NA & 32 & \\
\hline 7 & 51 & $\mathrm{~F}$ & VZV & No & NO & & OS & 15 & $\mathrm{HM}$ & NA & 79 & \\
\hline 8 & 62 & $\mathrm{~F}$ & VZV & No & NO & & OD & 1 & LP & 4 & 18 & \\
\hline 9 & 86 & $\mathrm{~F}$ & VZV & $\begin{array}{l}\text { Zoster ophthalmicus ( } 15 \text { days } \\
\text { prior) }\end{array}$ & NO & & OD & 7 & LP & NA & 13 & \\
\hline 10 & 81 & M & VZV & $\begin{array}{l}\text { Intercostal shingles (1 month } \\
\text { prior) }\end{array}$ & NO & & OD & 10 & $20 / 125$ & 2 & 21 & \\
\hline 11 & 59 & M & VZV & No & NO & & OD & 15 & $\mathrm{HM}$ & 4 & 15 & \\
\hline 12 & 82 & M & VZV & No & YES & $\begin{array}{l}\text { Multiple myeloma, } \\
\text { chemotherapy, } \\
\text { corticosteroids }\end{array}$ & OS & 21 & $20 / 100$ & 4 & 2 & \\
\hline 13 & 65 & $\mathrm{~F}$ & VZV & Shingles (15 days prior) & NO & & $O D$ & 7 & $20 / 63$ & 4 & 3 & \\
\hline 14 & 42 & M & VZV & $\begin{array}{l}\text { Intercostal shingles (30 years } \\
\text { prior) }\end{array}$ & NO & & OD & 2 & $20 / 25$ & 4 & 4 & \\
\hline 15 & 75 & $\mathrm{~F}$ & VZV & No & YES & $\begin{array}{l}\text { Kidney transplant, } \\
\text { immunosuppressive therapy, } \\
\text { corticosteroids }\end{array}$ & OS & 28 & $20 / 100$ & 3 & 3 & \\
\hline 16 & 40 & M & HSV1 & $\begin{array}{l}\text { Herpetic encephalitis (10 years } \\
\text { prior) }\end{array}$ & NO & & OS & 4 & $\mathrm{CF}$ & 4 & 37 & \\
\hline 17 & 47 & $\mathrm{~F}$ & HSV1 & $\begin{array}{l}\text { Herpetic encephalitis ( } 30 \text { years } \\
\text { prior) }\end{array}$ & NO & & OD & 4 & $\mathrm{HM}$ & 4 & 32 & \\
\hline 18 & 37 & $\mathrm{~F}$ & HSV1 & Herpetic encephalitis (neonatal) & NO & & Os & 15 & HM & NA & 65 & \\
\hline 19 & 51 & $\mathrm{~F}$ & HSV1 & $\begin{array}{l}\text { Herpetic encephalitis ( } 3 \text { months } \\
\text { prior) }\end{array}$ & YES & Lung cancer, chemotherapy & OS & 15 & $20 / 200$ & 3 & 2 & \\
\hline 20 & 34 & $\mathrm{~F}$ & HSV2 & $\begin{array}{l}\text { Herpetic keratitis } \\
\text { HSV2 neonatal }\end{array}$ & NO & & OS & 3 & $20 / 32$ & 4 & 61 & \\
\hline 21 & 20 & $\mathrm{~F}$ & HSV2 & $\begin{array}{l}\text { meningoencephalitis, intercostal } \\
\text { shingles ( } 10 \text { years prior) }\end{array}$ & NO & & OS & 30 & $20 / 200$ & 2 & 16 & \\
\hline 22 & 32 & M & HSV2 & No & NO & & OD & 3 & $20 / 125$ & 1 & 6 & \\
\hline 23 & 78 & M & CMV & No & YES & $\begin{array}{l}\text { Cavum lymphoma, } \\
\text { chemotherapy }\end{array}$ & OS & 45 & $20 / 40$ & 4 & 5 & \\
\hline 24 & 57 & $\mathrm{~F}$ & CMV & No & YES & $\begin{array}{l}\text { acute lymphoblastic } \\
\text { leukemia, chemotherapy }\end{array}$ & os & 7 & $20 / 40$ & 2 & 3 & \\
\hline
\end{tabular}

HSV: herpes simplex virus; VZV: varicella zoster virus; CMV: cytomegalovirus; VA: visual acuity; HM: hand motion; CF: counting fingers; LP: light perception; NA: not accessible; RD: retinal detachment; CRAO: central retinal artery occlusion; Age is expressed in years. 


\begin{tabular}{|c|c|c|c|c|c|c|c|c|c|c|c|c|}
\hline Patient & $\begin{array}{l}\text { qPCR } \\
\text { (number) }\end{array}$ & $\begin{array}{l}\text { Initial viral } \\
\text { load } \\
\text { (copies } / \mathrm{mL} \text { ) }\end{array}$ & IV treatment & $\begin{array}{l}\text { Duration of } \\
\text { IV antiviral } \\
\text { therapy } \\
\text { (days) }\end{array}$ & $\begin{array}{l}\text { Intravitreal } \\
\text { treatment }\end{array}$ & $\begin{array}{l}\text { Number } \\
\text { of } \\
\text { injections }\end{array}$ & $\begin{array}{l}\text { Prophylactic } \\
\text { laser }\end{array}$ & $\begin{array}{l}\text { High-dose } \\
\text { corticosteroid }\end{array}$ & $\begin{array}{l}\text { Anticoagulant } \\
\text { (AC) or } \\
\text { antiplatelet } \\
(\mathrm{AP}) \text { therapy }\end{array}$ & $\begin{array}{l}\text { Oral } \\
\text { medication } \\
\text { (maintenance) }\end{array}$ & Complications & $\begin{array}{l}\text { Final } \\
\text { VA }\end{array}$ \\
\hline 1 & 4 & 143000 & No & 0 & Foscarnet & 4 & No & No & No & Valacyclovir & $\begin{array}{l}\mathrm{RD}\left(5^{\text {th }}\right. \\
\text { month) }\end{array}$ & $20 / 63$ \\
\hline 2 & 17 & 43000 & Acyclovir & 30 & Ganciclovir & 14 & $\begin{array}{l}\text { PPR } \\
\text { (Neovascular } \\
\text { glaucoma) }\end{array}$ & No & No & Valacyclovir & $\begin{array}{l}\text { Neovascular } \\
\text { glaucoma }\end{array}$ & $20 / 50$ \\
\hline 3 & 16 & 131000 & Acyclovir & 48 & Ganciclovir & 23 & No & Yes & $\begin{array}{l}\text { AC (LMWH) } \\
2 \text { months, } \\
\text { then AP } \\
\text { (aspirin } \\
75 \mathrm{mg} / \text { day) }\end{array}$ & Valacyclovir & $\begin{array}{l}\text { Macular } \\
\text { edema }\end{array}$ & $20 / 125$ \\
\hline 4 & 10 & 380000 & Ganciclovir & 21 & Foscarnet & 13 & No & $\mathrm{No}^{*}$ & No & Valganciclovir & & $20 / 20$ \\
\hline $5(\mathrm{OD})$ & 23 & 13000000 & & & Ganciclovir & 26 & No & & & & & $20 / 63$ \\
\hline $5(\mathrm{OS})$ & 0 & & Acyclovir & 21 & Ganciclovir & 3 & No & $\mathrm{No}^{*}$ & No & Valacyclovir & $\begin{array}{l}\text { RD (at } \\
\text { presentation) } \\
\text { Macular }\end{array}$ & $\mathrm{HM}$ \\
\hline 6 & 1 & 22000 & Acyclovir & 28 & Ganciclovir & 2 & No & Yes & $\begin{array}{l}\mathrm{AP}^{*} \text { (aspirin } \\
75 \mathrm{mg} / \text { day) }\end{array}$ & Valacyclovir & $\begin{array}{l}\text { edema, } \\
\text { macular } \\
\text { epiretinal } \\
\text { membrane }\end{array}$ & $20 / 50$ \\
\hline 7 & 13 & 760000 & Foscarnet & 35 & Ganciclovir & 14 & Yes & No & $\begin{array}{l}\text { AP (aspirin } \\
75 \mathrm{mg} / \text { day) }\end{array}$ & Valacyclovir & $\begin{array}{l}\text { Macular } \\
\text { edema }\end{array}$ & $20 / 25$ \\
\hline 8 & 24 & 180873 & $\begin{array}{l}\text { Acyclovir then } \\
\text { foscarnet + ganciclovir }\end{array}$ & $31(10+21)$ & $\begin{array}{l}\text { Ganciclovir } \\
+ \\
\text { foscarnet }\end{array}$ & 25 & PPR (CRAO) & No & No & Valacyclovir & $\begin{array}{l}\text { CRAO (at } \\
\text { presentation) }\end{array}$ & LP \\
\hline 9 & 4 & 6100000 & Acyclovir & 21 & Ganciclovir & 2 & No & No & $\begin{array}{l}\mathrm{AP} * \text { (aspirin } \\
75 \mathrm{mg} / \text { day) }\end{array}$ & Valacyclovir & & LP \\
\hline 10 & 13 & 400000 & Foscarnet & 28 & Ganciclovir & 14 & Yes & Yes & $\begin{array}{l}\text { AP (aspirin } \\
75 \mathrm{mg} / \text { day) }\end{array}$ & Valacyclovir & $\begin{array}{l}\text { Macular } \\
\text { edema, } \\
\text { macular } \\
\text { epiretinal } \\
\text { membrane }\end{array}$ & $20 / 100$ \\
\hline 11 & 5 & 2000000 & $\begin{array}{l}\text { Acyclovir then } \\
\text { ganciclovir + foscarnet }\end{array}$ & $43(2+41)$ & Ganciclovir & 4 & No & Yes & $\begin{array}{l}\text { AP * (aspirin } \\
250 \mathrm{mg} / \text { day })\end{array}$ & Valganciclovir & $\begin{array}{l}\text { Macular } \\
\text { epiretinal } \\
\text { membrane }\end{array}$ & $20 / 63$ \\
\hline 12 & 11 & 1310000 & Acyclovir & 21 & $\begin{array}{l}\text { Ganciclovir } \\
+ \\
\text { foscarnet }\end{array}$ & 13 & No & $\mathrm{No}^{*}$ & No & Valacyclovir & & $20 / 100$ \\
\hline 13 & 1 & 478327 & Acyclovir & 15 & Foscarnet & 1 & No & Yes & AC (15 days) & Valacyclovir & & $20 / 25$ \\
\hline 14 & 1 & 10300 & Acyclovir & 15 & 0 & 0 & No & Yes & $\begin{array}{l}\text { AP (aspirin } \\
75 \mathrm{mg} / \text { day) }\end{array}$ & Valacyclovir & & $20 / 32$ \\
\hline 15 & 4 & 3302232 & Acyclovir & 21 & Foscarnet & 5 & No & $\mathrm{No}^{*}$ & $\begin{array}{l}\text { AP * (aspirin } \\
75 \mathrm{mg} / \text { day) }\end{array}$ & Valacyclovir & & $20 / 63$ \\
\hline 16 & 17 & 2700000 & Foscarnet then acyclovir & $30(15+15)$ & Ganciclovir & 28 & No & No & $\begin{array}{l}\text { AP (aspirin } \\
75 \mathrm{mg} / \text { day) }\end{array}$ & Valacyclovir & $\operatorname{RD}\left(2^{\text {nd }}\right.$ day $)$ & $20 / 100$ \\
\hline 17 & 11 & 185000 & Acyclovir & 28 & Ganciclovir & 13 & No & Yes & AP (aspirin & Valacyclovir & & $20 / 125$ \\
\hline
\end{tabular}




\begin{tabular}{|c|c|c|c|c|c|c|c|c|c|c|c|c|}
\hline & & & & & $\begin{array}{l}\text { then } \\
\text { foscarnet }\end{array}$ & (G7/F6) & & & $75 \mathrm{mg} /$ day) & & & \\
\hline 18 & 18 & 50000 & Acyclovir & 26 & Ganciclovir & 18 & No & No & No & Valacyclovir & Optic atrophy & LP \\
\hline 19 & 8 & 305000 & $\begin{array}{l}\text { Acyclovir then } \\
\text { foscarnet + acyclovir }\end{array}$ & $48(24+24)$ & Ganciclovir & 9 & No & Yes & $A C$ * $(L M W H)$ & Valacyclovir & & $\mathrm{HM}$ \\
\hline 20 & 8 & 2400 & Acyclovir & 24 & Ganciclovir & 8 & No & No & No & Valacyclovir & $\begin{array}{l}\mathrm{RD}\left(4^{\text {th }}\right. \\
\text { month) }\end{array}$ & $20 / 25$ \\
\hline 21 & 1 & 88400 & Acyclovir & 15 & 0 & 0 & No & Yes & $\begin{array}{l}\text { AP (aspirin } \\
75 \mathrm{mg} / \text { day) }\end{array}$ & Valacyclovir & $\begin{array}{l}\text { Macular } \\
\text { edema }\end{array}$ & $20 / 25$ \\
\hline 22 & 1 & 3010 & Acyclovir & 15 & 0 & 0 & No & Yes & No & Valacyclovir & & $20 / 20$ \\
\hline 23 & 6 & 213592 & Ganciclovir & 21 & Foscarnet & 6 & No & No & No & Valganciclovir & & $20 / 20$ \\
\hline 24 & 10 & 560000 & Ganciclovir & 21 & Foscarnet & 9 & No & No & No & Valganciclovir & & $20 / 100$ \\
\hline
\end{tabular}

qPCR: real-time PCR; IV: intravenous; IVT: intravitreal injection; VA: visual acuity; HM: hand motion; LP: light perception; RD: retinal detachment; PPR (panretinal photocoagulation);

G: ganciclovir; F: foscarnet; CRAO: central retinal artery occlusion; *: usual treatment; OD: ocular dexter; OS: ocular sinister; LMWH: Low molecular weight heparin 
Table 3. Retinal detachment rates reported in the literature

\begin{tabular}{|c|c|c|c|}
\hline $\begin{array}{l}\text { Publication } \\
\text { date }\end{array}$ & Author(s) & Number of eyes & RD rate \\
\hline 1982 & Fisher et al. ${ }^{31}$ & 41 & $50 \%$ \\
\hline 1989 & Clarkson et al. ${ }^{32}$ & 32 & $50 \%$ \\
\hline 1991 & Matsuo et al. ${ }^{33}$ & 26 & $50 \%$ \\
\hline 1993 & Crapotta et al. ${ }^{34}$ & 13 & $23 \%$ \\
\hline 1998 & Abe et al. ${ }^{13}$ & 12 & $50 \%$ \\
\hline 2004 & Tran et al. ${ }^{35}$ & 46 & $17.7 \%$ \\
\hline 2004 & Chau Tran et al. ${ }^{36}$ & 12 & $41.7 \%$ \\
\hline 2004 & Morel et al. ${ }^{37}$ & 22 & $50 \%$ \\
\hline 2007 & Lau et al. ${ }^{7}$ & 22 & $35.3 \%$ \\
\hline 2007 & Aizman et al. ${ }^{38}$ & 10 & $37.5 \%$ \\
\hline 2007 & Muthiah et al. ${ }^{39}$ & 12 & $75 \%$ \\
\hline 2009 & Ishida et al. ${ }^{40}$ & 18 & $33 \%$ \\
\hline 2009 & Sims et al. ${ }^{5}$ & 23 & $39 \%$ \\
\hline 2009 & Hillenkamp et al. ${ }^{41}$ & 30 & $73 \%$ \\
\hline 2010 & Meghpara et al. ${ }^{20}$ & 25 & $20 \%$ \\
\hline 2010 & Wong et al. ${ }^{42}$ & 81 & $47.0 \%$ \\
\hline 2010 & Tibbets et al. ${ }^{24}$ & 58 & $50 \%$ \\
\hline 2012 & Taylor et al. ${ }^{43}$ & 10 & $30 \%$ \\
\hline 2012 & Cochrane et al. ${ }^{44}$ & 52 & $30.8 \%$ \\
\hline 2012 & Luo et al. ${ }^{45}$ & 37 & $48.0 \%$ \\
\hline 2012 & Jeon et al. ${ }^{46}$ & 63 & $49.9 \%$ \\
\hline 2013 & Iwahashi-Shima et al. ${ }^{47}$ & 104 & $33 \%$ \\
\hline 2013 & Flaxel et al. ${ }^{48}$ & 29 & $45 \%$ \\
\hline 2013 & Bernheim et al. ${ }^{15}$ & 6 & $67 \%$ \\
\hline
\end{tabular}




\begin{tabular}{llll}
2014 & Roy et al. $^{4}$ & 63 & $66.1 \%$ \\
2015 & Winterhalter et al. $^{18}$ & 35 & $67 \%$ \\
2016 & Huang et al. ${ }^{49}$ & 29 & $45 \%$ \\
2016 & Calvo et al. $^{14}$ & 14 & $57 \%$ \\
2017 & Butler et al. & 41 & $59 \%$ \\
\hline
\end{tabular}

